\title{
The Implication of Pancasila Values on the Renewal of Criminal Law in Indonesia
}

\author{
Dian Alan Setiawan \\ Faculty of Law, Universitas Islam Bandung, Bandung, Indonesia \\ E-mail : dianalan.setia@yahoo.com
}
How to cite : Setiawan, Dian Alan. (2018). The Implication of Pancasila Values on the Renewal of Criminal Law in Indonesia. UNIFIKASI : Jurnal Ilmu Hukum, 5(2), 58-67.
DOI : $10.25134 /$ unifikasi.v5i2.948
Submitted : 11-04-2018 Revised : 16-04-2018 Accepted : 02-08-2018

\begin{abstract}
The current draft of the Criminal Code is inseparable from the idea that the legal characteristics in Indonesia are the adoption of the society's social order which is reflected in the living code of cultural values and social life in Indonesian society which is heterogeneous and plural. The existence of cultural values as a developing law in the society cannot be denied its role in a basic framework for the arrangement of national criminal law in the future. The problem examined in this research is formulated into the following questions: What are the influences of cultural values on the renewal of criminal law? What are the implications of Pancasila values on the development of the current criminal law? The method used in this research was normative legal research method where the law is conceptualized as a method. This research is a legal research using a conceptual and legislation approach that will review the related law. The results of this research provide an understanding to pay attention to the characteristics of criminal law in Indonesia in accordance with the characteristics of Indonesian citizen which is based on the philosophy of Pancasila. It needs to be emphasized since the future renewal of the Criminal Code is expected to be valid in a long term period so that the renewal needs to be done carefully and thoroughly, starting from its substance and structure, legal cultural values, to legal validity. Those aspects should be carefully considered so that the renewal of the Criminal Code is in line with law enforcement efforts which correspond to the society's demands in the reform era. Lastly, this research is expected to provide input to governments, especially to the related lawmakers and law enforcement officers, to make improvements and enhancements in the provisions concerning the influence of Pancasila values on the renewal of criminal.
\end{abstract}

Keywords: Renewal; Criminal Law; Pancasila; Indonesia

\section{Implikasi Nilai-Nilai Pancasila dalam Pembaharuan Hukum Pidana di Indonesia}

\begin{abstract}
Abstrak : Konsep Rancangan KUH Pidana yang ada sekarang ini tidak terlepas dari pemikiran bahwa karakteristik hukum di Indonesia merupakan adopsi dari tatanan sosial masyarakat yang tercermin dalam tata laku hidup nilai nilai budaya dan kehidupan sosial dalam keragaman masyarakat Indonesia yang heterogen dan plural. Keberadaan nilai nilai budaya sebagai hukum yang berkembang di masyarakat tidak dapat dipungkiri peranannya dalam suatu kerangka dasar penyusunan hukum pidana nasional di masa yang akan datang. Rumusan masalah yang ditelaah dalam penelitian ini apakah pengaruh nilai nilai budaya terhadap pembaharuan Hukum Pidana ? Apakah implikasi nilai pancasila terhadap perkembangan hukum pidana saat ini ? Metode yang digunakan dalam penelitian ini menggunakan metode penelitian hukum normatif, dimana hukum dikonsepkan sebagai kaedah. Penelitian ini merupakan penelitian hukum dengan menggunakan pendekatan konseptual dan pendekatan perundang-undangan yang akan meninjau kembali Undang-Undang terkait. Hasil penelitian ini memberikan pemahaman agar memperhatikan karakteristik hukum pidana sesuai dengan ciri khas kehidupan masyarakat Indonesia yang hidup berdasarkan falsafah Pancasila. Hal ini perlu ditekankan karena pembaharuan KUH Pidana ke depan diharapkan dapat diperlakukan dalam jangka panjang sehinga perlu digarap dengan cermat dan teliti substansi maupun struktural, nilai budaya hukum, sampai validitas hukum (daya berlaku). semua itu dimaksudkan agar pembentukan KUH Pidana yang baru tersebut tidak menjadi sia-sia dengan upaya penegakan hukum yang sesuai dengan tuntutan masyarakat dalam era reformasi. Simpulan dan saran dalam penelitian ini diharapkan memberi masukkan kepada pemerintah terutama kepada para pembuat undangundang dan para penegak hukum terkait untuk melakukan penyempurnaan dan perbaikan dalam ketentuan mengenai nilai-nilai pancasila yang memberikan pengaruh terhadap pembaharuan hukum pidana.
\end{abstract}

Kata Kunci: Pembaharuan; Hukum Pidan; Pancasila; Indonesia

\section{INTRODUCTION}

A country should be based on law in all respects. It has been coveted since Plato wrote "Nomoi", E. Kant described the principles of the State of Law (formal), J. Stahl presented the State of Law (material), and Dicey proposed a "Rule of Law" ${ }^{1}$. Briefly, a country is called an

1 Padmo Wahyono,1982, Indonesia Negara Berdasarkan Atas Hukum, Jakarta : Ghalia Indonesia, ideal country in the 20th century if all state activities are based on law. The history shows that this understanding always develops following the level of intelligence of a nation. As outlined by the Constitution formers, Indonesia is a law-based country with the

sebagaimana tertulis dalam Oemar Seno Adji, Indonesia Negara Hukum dalam Seminar Ketatanegaraan UUD 1945 
formula of "Rechstaat". It applies with the assumption that the pattern does not deviate from the meaning of the State of Law in general (genusbrip) and is adjusted to the conditions in Indonesia. It means that it is used based on our view of life and our state view ${ }^{2}$.

Satjipto Rahardjo states that law does not just fall from the sky, but it grows and develops along with the growth of the society ${ }^{3}$. Law should always be associated with society wherever the law works. The field of legal knowledge generally focuses on rules that are considered valid by the government and society and, therefore, it must be obeyed. On the other hand, sociological knowledge focuses on actions realized by the society members in their daily life. Therefore, to create a unity between legal development and legal knowledge, we must pay attention to the law and the realities in the society. This fact often gives the impression that legal knowledge is now far from sociological knowledge, even it is frequently considered that law experts does not need sociological knowledge. Yet, this impression does not correspond to the reality since when examining legal knowledge, there will be found many elements connecting the rules with the realities occurred in individual relationship as a society member.

Law actually has a reciprocal relationship with the society, where the law is a means/tool to regulate the society and work within the society itself, the society can become an obstacle or a means/social tool enabling the law to be applied as well as possible. It means that law is strongly influenced by non-legal factors, such as: values, attitudes and society's views which are commonly referred to as legal culture. The existence of this legal culture causes the differences in law enforcement between one society and another.

Lawrence M. Friedman describes that law as a system has the following components ${ }^{4}$ :

a. Structure is in the form of institutions created by the legal system to support the operation of the legal system itself, such as: district courts, administrative courts, etc.;

\footnotetext{
${ }^{2}$ Ibid., pp. 7

${ }^{3}$ Satjipto Rahardjo, 2008, Membedah Hukum Progresif, Jakarta: Penerbit Buku Kompas. Pp.16

${ }^{4}$ Lawrence. M. Friedman, 1986, The Legal System. A Social Science Perspective, New York: Russel Sage Foundation.
}

b. Substance is in the form of legal norms used by law enforcement officers and those who are regulated;

c. Legal culture is in the form of ideas, attitudes, expectations, and opinions about the law which affect a person as a whole to be obedient or disobedient towards the law.

The thing that we must hold in this regard is no matter how good the law is created, in the end, it will be then strongly influenced by the legal culture in the form of values, views and attitudes of the society concerned. If the legal culture is ignored, it can be confirmed that there will be a failure of the modern legal system which is characterized by the emergence of various phenomena, such as: misinformation concerning the contents of the legal regulations intended to be conveyed to the society, and a gap exists between what is expected by the law and practices carried out by the society. Society prefers to keep behaving based on what have become the values and views in their lives. Law enforcement in Indonesia that still adheres to the legal understanding of positivism, a discriminatory justice, the existence of legal and judicial mafia, the existence of engineering in the judicial process are portraits and realities in law enforcement in our country. Discriminatory justice makes the law in this country exactly as Plato described that "laws are spider webs, they hold the weak and delicates who are caught in their meshes but are torn in pieces by the rich and powerful" 5 . Some ordinary people who were caught doing small thefts, such as Grandma Minah who took three cocoa beans in Purbalingga, and Kholil and Basari in Kediri who stole two watermelon seeds, were immediately arrested and punished. On the other hand, the officials and political elites who commit corruption up to tens of billions, its legal processes are convoluted and have not reached a clear decision, and in many legal decisions, are severed and do not correspond to the losses caused either morally or materially.

Various examples of law enforcement cases in Indonesia, such as Century Bank, Nazarudin, BLBI funds, Artalita, Nunun Nurbaeti, Miranda Gultom, Angelina Sondakh, Hambalang, and many other cases, its decision

${ }^{5}$ Moh. Mahfud MD, 2010, Keniscayaan Reformasi Hukum: Upaya Menjaga Jati Diri Dan Martabat Bangsa, Makalah dalam Konvensi Kampus VI dan Temu Tahunan XII Forum Rektor Indonesia (FRI) di Universitas Tanjungpura Pontianak. 
was unsatisfactory and only sentenced to several years and fines that are not too high even though the case is so detrimental to the state and society.

In relation to law enforcement in Indonesia which still adheres to the legal understanding of positivism, this becomes an obstacle in law enforcement since legal positivism is widely applied especially in articles and procedures in the criminal field. Lawsuits are frequently filed only on the basis of fulfilling or not fulfilling the elements of the criminal law rules without considering the aspects of justice and values prevailing in the society. The face of law enforcement, especially criminal law enforcement, is only effectively enforced for small societies or weak people, while for the officials, political elites, power holders who commit corruption, for example, which have a greater effect, are only given legal sanctions that are not equal and do not give a deterrent effect.

The weaknesses of legis positivism exist because the standard used for evaluating an act carried out by an individual or society group, as expressed by Hans Kelsen, is a valid legal norm (articles and procedures in the legislation/written regulations). This written regulations are used as a measure to punish a person or not, to sentence a person guilty or not, without considering the aspects of moral and justice. In order to create a better law enforcement, according to Barda Nawawi, legal reform does not only mean the legal substance reform, but also the legal structure reform and the legal culture reform including legal ethics and legal education ${ }^{6}$.

From the description, it is clear that law enforcement is not only determined by its own legal rules, facilities, and the mentality of law enforcement officers, but it also strongly depends on the factors of society awareness and compliance. In the end, it returns to the human element (culture) which also determines the true pattern; in the last analysis it is the human being that counts. Therefore, a good and right law does not automatically guarantee a good and right society life. Besides, the presence of police, prosecutors, judges, lawyers as direct and formal law enforcement does not guarantee the enforcement of the law and the enactment

6 Supriyanta, Volume VII Edisi April 2008 "Demokratisasi Dalam Penegakan Hukum", Wacana Hukum, Jurnal Hukum Unisri. pp .93 of rule of law. Even if the parliament is elected through an election with a large cost, democracy will not automatically grow.

The current draft of the Criminal Code is inseparable from the idea that the legal characteristics in Indonesia are the adoption of the society's social order which is reflected in the living code of cultural values and social life in Indonesian society which is heterogeneous and plural. The existence of cultural values as a developing law in the society cannot be denied its role in a basic framework for the arrangement of national criminal law in the future. The noble values contained in Pancasila as the ideology of the nation should not only be known, but it should also be understood which is then implemented in various aspects of life. The same treatment for every Indonesian citizen in law should also apply the noble values contained in Pancasila, namely justice for all Indonesian which does not discriminate any aspects of life, decisions taken through deliberation, the unity of the nation that does not attach personal and group importance, as well as responsibility towards $\operatorname{God}^{7}$. Finally, by looking at the importance of this issue, this research tries to describe the implications of Pancasila values in the renewal of criminal law in Indonesia in order to realize a national criminal law that is responsive, or corresponds to the personality of the nation. The problems examined in this research are then formulated into the following questions: 1) What are the influences of cultural values on the renewal of criminal law? and 2) What are the implications of Pancasila values on the development of the current criminal law?

\section{METHOD}

The method used in this research is normative juridical method in which this research focuses on examining the implementation of norms in positive law ${ }^{8}$. Normative Juridical is a legal research conducted by examining library materials or secondary data as the basic materials to be investigated by searching any regulations and

\footnotetext{
${ }^{7}$ Laurensius Arliman S, Volume 05 Nomor 01, Januari 2018, perlindungan hukum bagi anak dalam perspektif pancasila dan bela negara, Jurnal Ilmu Hukum Unifikasi, Kuningan, FH. Uniku.

${ }^{8}$ Johny Ibrahim, 2012, Teori dan Metodologi Penelitian Hukum Normatif, Malang : Bayumedia publishing, pp.25
} 
literatures relating to the problems under study ${ }^{9}$. This research uses the statute and conceptual approach ${ }^{10}$. Moreover, the data are collected through library research by searching the principles of law, legislation and other documents relating to the problems under study $^{11}$.

\section{RESULTS AND DISCUSSION \\ The Influences of Cultural Values on the Renewal of Criminal Law}

From the 6th to the 18th century, criminal law was carried out solely to frighten a person from committing a crime by imposing a very severe sentence. The death penalty, for example, was carried out in various terrible ways in which the goal at that time was to protect society from committing crimes. These conditions then led to a movement towards renewal of the criminal law system. The desire to reform criminal law, especially the Criminal Code has been existed since 1946 on the grounds that this criminal law was a Dutch colonial legacy. The need for the renewal of criminal law becomes important by paying attention to the characteristics of criminal law with an Indonesian perspective (cultural values). In the future, the character of the new Criminal Code should be aimed at and adjusted to the spirit of reform in the field of law. The renewal of criminal law should be pursued optimally as a primary need for the nation and state in this century. The renewal of criminal law should be absolutely begun considering that the current Criminal Code is quite old. In the Netherlands, the Criminal Code, originally named Wetbook van Strafrecht voor Nederlands indie, was renamed Wetbook van Strafrecht $(W v S)$ or the Criminal Code. In the Netherlands, the Criminal Code was valid since 1886 as a substitute for the French Penal Code promulgated in 1811 when the Dutch were still colonized by France. Yet, the WvS in the Netherlands has undergone changes and developments several times in accordance with the development of the Dutch life. Lastly, WvS was completely replaced with the new WcS based on the 1989 Staatsblaad No. 7 Year

\footnotetext{
9 Soerjono Soekanto dan Sri Madmuji, 2015, Penelitian Hukum Normatif : Suatu Tinjauan Singkat. Jakarta : PT RajaGrafindo Persada, pp. 49

${ }^{10}$ Peter Mahmud Marzuki, 2010, Penelitian Hukum, Cet. 6, Jakarta: Kencana Prenada Media Group, hlm. 35.

${ }^{11}$ Ibid., pp.93
}

1989. The legacy of the Dutch Criminal Act was enacted through the concordance principles with 1915 Staatsblaad No. 732 since $1918^{12}$.

The national development is not only done to pursue and fulfill external needs of clothing, shelter and food, but also requires internal satisfaction in the form of security, a sense of fairness and so on. The welfare and harmony of human life will be disrupted if there is no sense of security in the social life, there is no peace of life, and there is no guarantee of fair treatment. A safe and peaceful life from disturbances or the attitude of other society members who violate the values of truth, honesty is a very basic social and cultural need of the society. This fundamental need is needed to ensure a healthy and meaningful life. If the fundamental needs of social and cultural values are not fulfilled, there will be frustration and anxiety in human life which can bring the destruction of human existence and the integrity of the society itself.

The total renewal and replacement is now urgently needed to adapt to the situation of the society which has undergone many changes, especially after the amendment to the 1945 Constitution. The desire to realize law enforcement, democracy, human rights and clean governance has now become a demand of the society which cannot be postponed anymore. Actually, efforts to reform criminal law have started since the beginning of the Republic of Indonesia, when the proclamation of independence on August 17, 1945 to avoid the legal vacuum of the 1945 Constitution containing the Transitional Rules. In the Transitional Rules Article 11 states "all state officers and regulations that still exists will immediately valid as long as there are no new ones according to this Constitution". This provision means that the criminal law and criminal Act applied at that time, namely during the period of Dutch and Japanese colonization, are declared to remain valid before a new law. In 1944, the Japanese government issued Gunzei Keizerei like a Criminal Code which should be applied by the court in criminal cases. These conditions last until the issuance of Law No. 1 in 1946 on February 26, 1946 by the Soekarno-Hatta Government. Then, it continues with efforts to

\footnotetext{
${ }^{12}$ Moh. Hatta, 2016, Kapita Selekta Pembaharuan Hukum Pidana dan Sistem Pemidanaan, Yogyakarta : Liberty, pp. 1
} 
amend the Criminal Code, especially concerning national symbols and flags as well as the flags of friendly countries based on Law No. 1973 Year 1958, and at that time, it could be said that the renewal of criminal law was begun by Indonesian lawmakers.

The reform of criminal law should refer to criminal law policies that can support criminal and law enforcement policies. Law enforcement policies include anything that can be criminalized in criminal law so that it will not cause tensions and oppositions from the society. The existence of the National Criminal Code also aims to educate convicts in the right direction as other society members. The formulation of criminal objectives should also protect the society. A common understanding of the needs of the new Criminal Code in Indonesia should pay attention to the characteristics of criminal law in accordance with the characteristics of Indonesian citizens who live based on the philosophy of Pancasila. It needs to be emphasized since the future renewal of the Criminal Code is expected to be valid in a long term period so that the renewal needs to be done carefully and thoroughly, starting from its substance and structure, legal cultural values, to legal validity. Those aspects should be carefully considered so that the renewal of the Criminal Code is in line with law enforcement efforts which correspond to the society's demands in the reform era.

The need for the renewal of criminal law is related to the substance of the Criminal Code itself. In college, the teaching of criminal law to students directly or indirectly will teach and give understanding about dogma, principles, and concepts as well as mindset and substantive norms. For example, the current Criminal Code which we use, in its formation at that time, was based on liberalismindividualism which was strongly influenced by classical and non-classical ideologies on criminal law as well as the criminal theory of Dutch colonial in its colonies. The existence of the new Criminal Code which has national characters in accordance with Pancasila and the 1945 Constitution is urgently needed to be realized replacing the old Criminal Code of the Dutch colonial which is no longer suitable with the development of social, cultural, regional and global economic and political values in Indonesia. With the establishment of the new Criminal Code, it will reflect the government's serious efforts in criminal law enforcement. In addition, the presence of the new Criminal Code is expected to be able to realize criminal law enforcement that is more humane by the government and law enforcement officers in a clean and authoritative government. The law enforcement should correspond to the spirit and ideals of Indonesian citizens by creating justice and legal certainty as well as benefits for society.

The establishment of criminal law should include material law policies, formal criminal law and criminal law implementation. All of them are related to (a) criminalization and decriminalization, (b) criminal sanctions, (c) the implementation of criminal law, and (d) the urgency of the National Criminal Code. Everything will be answered by criminal policies. According to Barda Nawawi Arief, the criminal law policy will go through three stages: ${ }^{13}$

a. The abstrakto law enforcement stage by the law-making agency is referred to as the legislation policy as a law formulation stage;

b. The concreto law enforcement stage on the implementation of criminal law by law enforcement officers in the police station, prosecutor's office to the court is called the judicial policy as a law application stage;

c. The concreto law enforcement stage on the criminal execution by executing officers is referred to as the executive policy as an administrative/legal execution stage.

The three stages can be applied sequentially starting with the stage of the establishment of the Criminal Code. The current establishment of the Criminal Code is only at the first stage, namely the formulation of criminal law. In this stage, all legal aspects and types of criminal sanctions can be proposed by citizens as an input for the government on the realization of a new Criminal Code that can fulfill the sense of justice of Indonesian citizens.

Law in Indonesia is a combination of European law system, religious and customary law. Some of the systems adopted, both civil and criminal, are based on continental European law, especially from the Netherlands since, as we know that, Indonesia is a colony with the designation of the Dutch East Indies

\footnotetext{
${ }^{13}$ Barda Nawawi Arief, 2003, Kapita Selekta hukum Pidana, Bandung: Citra Aditya, pp. 42
} 
(Nederlandsch Indie). Second, since most of Indonesian adheres to Islam, then the domination of Islamic law is more apparent especially in the field of family and inheritance. In addition, in Indonesia, the customary law system also applies so that it is then absorbed in legislation or jurisprudence which is the continuation of local rules and cultures. Basically, the law reflects the values that live in society. Today, Indonesia is experiencing a transition which is a values change in society, namely from traditional to modern values. Some examples of legislation serving as a means of renewal in the sense of changing the mental attitude of traditional society towards the modern are the prohibition on the use of koteka in Papua, the necessity of creating land certificates, etc.

Cultural values are values that are agreed upon and embedded in a society, organizational scope, or society environment, rooted in a habit, belief, and symbols with certain characteristics that can be distinguished from one another as behavioral references and responses to what will happen or is happening. Cultural values will appear in symbols, slogans, motto, vision mission, or something that appears as a basic reference for the motto of an environment or organization. ${ }^{14}$ Nobody denies that customary law is an unwritten law that lives, grows, and develops in the society (the living law). Consciously or not, we have implemented cultural values of customary law every day in various socio-cultural activities in the society by implementing local wisdom. Mutual cooperation activities, mutual helps, deliberation to solve a problem are concrete examples of the implementation of customary law.

This legacy of the Dutch East Indies era Criminal Code comes from the continental legal system (civil law system) or Rene David called it as the Romano-Germanic Family. The Romano Germanic family is influenced by the ideologies emphasizing on individualism and liberalism (individualism, liberalism, and individual right). ${ }^{15}$ This is very different from the culture (legal culture) of Indonesian citizens who uphold social values. If the current

\footnotetext{
14 Nilai-nilai budaya, http://id.wikipedia.org, diakses tanggal 16 Februari 2018

15 Ahmad Bahiej, Vol. 5 No. 2 2006, Sejarah dan Problematika Hukum Pidana Materiel di Indonesia, Jurnal Sosio-Religia : Lingkar Studi Ilmu Agama dan Ilmu Sosial, Yogyakarta. pp.16.
}

Criminal Code is then forced to remain valid, the clash of values and interests can arise and may lead to new crimes. The concepts, legal system, and legal theories used in the current Criminal Code are still binding on the law taken by Dutch, even though Dutch legal culture is different from Indonesian legal culture that upholds the morals of Indonesian citizens. Therefore, the renewal of criminal law in Indonesia should reflect the attitude of Indonesian legal culture.

In the effort of reforming Indonesia's material criminal law, the new Criminal Code (KUHP) has been submitted by the government to DPR RI in early March 2013. With the draft Criminal Code, it is expected to improve the law in Indonesia. The legal material in the draft Criminal Code should be explored and made based on the values in the form of legal awareness and ideals (rechtsidee), moral ideals, individual and national independence, humanity, peace, political ideals, and state goals. The law reflects the values of life in society which may apply juridically, sociologically and philosophically. The role of law should be more highlighted as a means of protecting interests or law as a protection of human interest, and as a means of public supervision or law as a tool of social control. In general, law is essentially implied social responsibility of how a person or a group should behave in society. ${ }^{16}$

Is the Criminal Code which is not rooted in Indonesian culture difficult to apply? Brian Z. Tamanaha ${ }^{17}$ with his theory "mirror thesis" states that "The Law Society Framework" has the characteristics of a particular relationship, where the relationship is indicated by the idea that law is a "mirror" of a society and the idea that the legal function is to maintain "social order." The correlation with Indonesia is that the colonial inheritance law cannot necessarily be applied in Indonesia since we should look at the social conditions of the society.

Until now (2018), the draft of Criminal Code is still being reviewed to improve the colonial inheritance criminal code in which the process is strongly influenced by various

${ }^{16}$ Soejadi, 1998, Pancasila sebagai Sumber Tertib Hukum Indonesia, Yogyakarta: Universitas Gadjah Mada, pp. 60

Brian Z. Tamanaha, 2006, The Generale Jurisprudence of Law and Society, New York: Oxford University Press, pp. 1-2. 
factors, including political factors. Barda Nawawi Arief $^{18}$ as one of the figures who took part in the birth of the RKUHP, says: The length of the change/renewal of the Criminal Code is not a problem. The problem is the effect/impact it causes. As long as the Dutch legacy of the Criminal Code/WvS (which is the prime of the criminal law system) has not been replaced, during this time, there was "a colonization of the criminal law system". It means that there is colonization (rape/confinement/murder) of the noble values of the national legal culture and the values that grow in the society". In fact, it can be said that the longer the legal system of the colonials is applied, the more displaced/deterred the character of the national identity that is expected to be built. It is really hard to imagine that how the quality of people's lives with the characteristics of Pancasila can be realized, if the legal system itself is not characterized by Pancasila.

Indonesian legal culture that upholds moral, religious and cultural values is reflected in the principles of Pancasila as an ideology that is ontologically, epistemologically and axiologically rooted in the noble values upheld and internalized by society. The new draft of Criminal Code should be formed in accordance with the legal culture which is based on Pancasila as a legal and ideological culture that is ontologically, epistemologically and axiologically rooted in noble values upheld and internalized by society and should be based on sociological jurisprudence thinking that a good law is law which corresponds to the law lived in society. The society should play a role in creating a legal culture regarding criminal law enforcement in Indonesia in the form of individual awareness and compliance. The society should avoid practices of criminal offenses such as corruption, collusion, nepotism, money bribery, and other various criminal acts. The law enforcement in Indonesia eventually returns to the legal culture that was created and chosen by the society, the law enforcement officers, and the government.

\section{The Implications of Pancasila Values on the Renewal of Criminal Law}

18 Barda Nawawi Arief, 2014, Bahan Pelatihan/Penataran Asas-asas Hukum Pidana dan Kriminologi, diselenggarakan oleh FH UGM Yogyakarta dan Mahupiki, di University Club UGM Yogyakarta
The development of the national legal system (criminal law) should be rooted in the noble values contained in Pancasila so that it is in accordance with the national spirit (volkgeits). The law that grows and develops by integrating the noble values of the society, in turn, will be able to produce an aspirational and accommodating law in accordance with the mainstream of its society. In relation to the necessity as well as the mandate to use the values of Pancasila especially the precept $\mathrm{I}$, it is clearly stated in the national legal system: (a) Article 29 paragraph (1) of the 1945 Constitution: The State is based on the belief in the God Almighty; (b) Article 3 paragraph (2) of Act Number 4 of 2004 concerning Judicial Power: "State courts apply and enforce law and justice based on Pancasila".

Indonesia is a state of law as it is affirmed in Article 1 (3) of the 1945 Constitution of Republic of Indonesia that a variety of existing regulations should be based on the values of Pancasila. As a state of law which is based on Pancasila values, according to Bernard Arief Sidharta as written in Teguh Prasetyo's book, Indonesia has three main characteristics, namely ${ }^{19}$ :

a. In the legal state of Pancasila, all power uses should always have a legal basis and be within the framework of the limits set by law, afortiory for the power use. So, the desired government is government that is based on and by law (rule by law and rule of law).

b. The legal state of Pancasila is a democratic country in which all state activities are always open to rational evaluation by all parties within the framework of applicable values and law system. Besides, the judiciary operates its authority freely and other government bureaucracies are subject to judiciary's decisions and the society can propose the bureaucracy actions of the government to the court. The government is open to critical evaluation proposed by the representatives and the society concerning the policies and actions.

c. The legal state of Pancasila is an organization of all people who organize themselves rationally within the framework and through the rule of law to realize the

\footnotetext{
${ }^{19}$ Teguh Prasetyo dan Ari Purnomosidi, 2014, Membangun Hukum berdasarkan Pancasila, Nusa Media, Bandung, pp. 59.
} 
welfare for all society by referring to the values and Godhead.

According to Barda Nawawi Arief, if what the National Law System aspires to is the Pancasila Legal System, then the Criminal Law System (containing values) of Pancasila should be studied and developed, namely criminal law which is oriented to the values of "God Almighty", criminal law which is "fair and civilized humanity", criminal law which contains the values of "unity" (such as: does not differentiate tribes/groups/religions, prioritizing public interests), criminal law which contains the values of "democracy" (such as: prioritizing public interests/welfare, resolving conflicts wisely through deliberation), and the criminal law which contains "social justice". This is a big problem that is challenging and has not been resolved ${ }^{20}$.

The judicial system (or law enforcement system - abbreviated as SPH), if it is seen integrally, is a unity of various subsystems (components) consisting of "legal substance", "legal structure" and "legal culture". The linkages between the three components can be illustrated as the "running a car" system. If the law is illustrated as a tool/means in the form of a car to achieve a certain goal, then "enforcing the law" is essentially identical to "running a car". Cars/vehicles (identical to "legal substance") can only run if there is a "driver" (identical to "legal structure", apparatus/law enforcement officers) and the driver should also "be expert in running a car" (have a driver's license). The skill of running a car is synonymous with "legal science" (the science of enforcing the law) which includes "legal culture". Thus, it should be emphasized that a driver's license is not enough. The driver should also know the environmental conditions. If he does not know, he may get lost. It means that law enforcement should pay attention to the Indonesian context, especially the Indonesian legal environment (i.e. the national legal system/SISKUMNAS).

The judicial/law enforcement system is essentially a unity of substantial, structural, and cultural system. Then, the scope of the renewal of law enforcement system includes "substantial reform", "structural reform", and "cultural reform".

${ }^{20}$ Selengkapnya dalam Barda Nawawi Arief, 1994, "Menyongsong Generasi Hukum Pidana Indonesia", Pidato Pengukuhan Guru Besar di FH Undip, Semarang
The rise of various judicial mafia cases is an indicator of the decline of the quality of religious and scientific approaches. Here, it is not "jurisprudence" which is used, but "other knowledge/approach" (bribes; power/political approach; etc.). If law figures are used, it seems to use "extract and partial law" or "horse-eyeglass law", namely:

1) Separating between "the norms of the Law with the principles, the punishment goals, and the basic values/ideas which are existed and recognized in the unwritten science/theory/law";

2) Separating "legal certainty/against formal law from legal certainty/against material law";

3) Separating "law" and "legal science"; many people know about "law", but do not know or forget the "knowledge" (legal science).

4) Separating "legal science" from "divine science (moral/religion)"; many people are aware of "law guidance", but ignorant of the meaning of "justice based on God Almighty";

5) Separating "the three main issues of Criminal Law (criminal offense; error; criminal) from the whole criminal system";

6) Separating "criminal law enforcement" from "the national law enforcement system"; or separating the "HP system with SISKUMNAS".

In essence, the quality of law enforcement cannot be separated from the goal of improving the life quality of the society and the quality of sustainable development (sustainable society). The existence of "judicial mafia" (which is a form of law enforcement without "legal science" and "divinity") can damage "sustainable development/sustainable society" since development resources is not only natural resources/physical, but it also involves non-physical resources. The criminal justice system (SPP) which is good, which can ensure justice and the security of citizens, which is fair, responsible , ethical and efficient, and which can foster public trust and respect ${ }^{21}$, is basically a non-physical resource that needs to be maintained for the next generation. The judicial mafia is essentially a form of exploitation which damages non-physical resources and can become a "virus" for ideal

\footnotetext{
${ }^{21}$ Terungkap dalam dokumen dan resolusi Kongres PBB ke-9/1995 mengenai mengenai "Prevention of Crime and the Treatment of Offenders"
} 
SPP; it means that it can damage the life quality of the society.

In one part of the Conclusion of the VI/1994 National Law Seminar, it was stated: "It is necessary to develop ideas about the quality of justice (the dispension of justice) which is more compatible with the Pancasila legal system". From this statement, it can be clearly seen that there is a need to develop justice characterized by Indonesia, namely "Pancasila justice", which implies "divinity justice", "humanistic justice", "democratic, nationalistic and social justice". It means that the upheld justice is not only the formal justice, but also the substantial justice, especially in criminal justice which emphasizes material justice/truth, not formal justice/truth as in civil court. By utilizing an integral scientific approach (legal thinking) between the juridicalscientific-religious approach, the juridicalcontextual approach, the juridical-cultural approach, and the juridical approach with a global/comparative perspective, it is expected that law enforcement can also contribute to the realization of law reform and development in Indonesia.

\section{CONCLUSION}

The total renewal and replacement of the current criminal law is now urgently needed to adapt to the situation of the society which has undergone many changes, especially after the amendment to the 1945 Constitution. The desire to realize law enforcement, democracy, human rights and clean governance has now become a demand of the society which cannot be postponed anymore. It is because the criminal law should correspond to Indonesian culture (legal culture) which upholds social values. If the current Criminal Code is then forced to remain valid, the clash of values and interests can arise and may lead to new crimes. The concepts, legal system, and legal theories used in the current Criminal Code are still binding on the law taken by Dutch, even though Dutch legal culture is different from Indonesian legal culture that upholds the morals of Indonesian citizens. Therefore, the renewal of criminal law in Indonesia should reflect the attitude of legal culture in Indonesia.

The development of the national legal system (criminal law) should be rooted in the noble values contained in Pancasila so that it is in accordance with the national spirit (volkgeits). The law that grows and develops by integrating the noble values of the society, in turn, will be able to produce an aspirational and accommodating law in accordance with the mainstream of its society. The judicial system (or law enforcement system - abbreviated as $\mathrm{SPH}$ ), if it is seen integrally, is a unity of various sub-systems (components) consisting of "legal substance", "legal structure" and "legal culture". If what the National Law System aspires to is the Pancasila Legal System, then the Criminal Law System (containing the values) of Pancasila should be studied and developed.

\section{SUGGESTION}

This research is expected to provide general input for the development and renewal of Legal Science especially in the field of Criminal Law relating to the influence of Indonesian cultural values. In addition, it is expected that the government, especially to law enforcement officers and legislators (legislative), will be able to make improvements and enhancements in the provisions concerning the implication of Pancasila values on the renewal of criminal law in Indonesia in which the law should reflect the legal culture in Indonesia and based on law that grows and develops by integrating the noble values of the society so that an aspirational and accommodating law in accordance with the mainstream of the society can be produced.

\section{REFERENCES}

Ahmad Bahiej, Februari (2006). Sejarah dan Problematika Hukum Pidana Materiel di Indonesia, Sosio-Religia, Vol. 5 No. 2, Jurnal Sosio-Religia : Lingkar Studi Ilmu Agama dan Ilmu Sosial, Yogyakarta

Barda Nawawi Arief, (1984). "Menyongsong Generasi Hukum Pidana Indonesia", Pidato Pengukuhan Guru Besar di FH Undip Semarang.

Barda Nawawi Arief (2003). Kapita Selekta hukum Pidana, Bandung: Citra Aditya.

Barda Nawawi Arief (2014). "Bahan Pelatihan/Penataran Asas-asas Hukum Pidana dan Kriminologi", diselenggarakan oleh FH UGM Yogyakarta dan Mahupiki, di University Club UGM Yogyakarta. 
Brian Z. Tamanaha, 2006. The Generale Jurisprudence of Law and Society, (New York: Oxford University Press.

Herbert L. Packer, (1968). The Limits of The Criminal Sanction .Stanford, California, Stanford University Press.

Johny Ibrahim, (2012). Teori dan Metodologi Penelitian Hukum Normatif, Malang ; Bayumedia publishing.

Laurensius Arliman S, (2018). Perlindungan Hukum Bagi Anak Dalam Perspektif Pancasila Dan Bela Negara, UNIFIKASI : Jurnal Ilmu Hukum.5(1).

Lawrence. M. Friedman, (1986). The Legal System. A Social Science Perspective, New York: Russel Sage Foundation.

Lawrence. M. Friedman, (1984). "What Is a Legal System" dalam American Law. W.W. Norton \& Company, New York.

Moh. Hatta, (2016). Kapita Selekta Pembaharuan Hukum Pidana dan Sistem Pemidanaan, Yogyakarta : Liberty.

Moh. Mahfud MD, (2010) "Keniscayaan Reformasi Hukum: Upaya Menjaga Jati Diri Dan Martabat Bangsa", Makalah dalam Konvensi Kampus VI dan Temu Tahunan XII Forum Rektor Indonesia (FRI) di Universitas Tanjungpura Pontianak.

Nils Jareborg menyebutnya sebagai "the structure of penal system" (lihat: "THE COHERENCE OF THE PENAL SYSTEM" Dalam Criminal Law in Action, J. J. M. van Dijk, 1988, Arnhem,

Oemar Seno Adji. (2010), Indonesia Negara Hukum dalam Seminar Ketatanegaraan UUD 1945

Padmo Wahyono, (1982). Indonesia Negara Berdasarkan Atas Hukum, Jakarta : Ghalia Indonesia

Peter Mahmud Marzuki, 2010. Penelitian Hukum, Cet. 6, Jakarta: Kencana Prenada Media Group.

Pujiyono, (2012). Rekonstruksi sistem peradilan pidana indonesia dalam perspektif kemandirian kekuasaan kehakiman, Masalah-Masalah Hukum: 41(1).

Rahardjo, Satjipto. (2008). Membedah Hukum Progresif, Jakarta: Penerbit Buku Kompas.

Soejadi, (1998). Pancasila sebagai Sumber Tertib Hukum Indonesia, Yogyakarta: Universitas Gadjah Mada.
Soerjono Soekanto dan Sri Madmuji, (2015). Penelitian Hukum Normatif : Suatu Tinjauan Singkat. Jakarta : PT RajaGrafindo Persada.

Supriyanta, (2008). "Demokratisasi Dalam Penegakan Hukum", Wacana Hukum :VII. April 2008. 